\title{
KEPRIBADIAN TOKOH JAMILA DALAM NASKAH DRAMA “PELACUR DAN SANG PRESIDEN” KARYA RATNA SARUMPAET DITINJAU DARI GERAKAN FEMINISME LIBERAL
}

\author{
Muhammad Bayu Gumelar, Ajat Sudrajat, Arip Hidayat \\ Pendidikan Bahasa dan Sastra Indonesia Universitas Kuningan \\ Jalan Cut Nyak Dien no. 36 A Kuningan Jawa Barat \\ Pos-el : bayugumelar05@gmail.com HP: 089691180779
}

\begin{abstract}
ABSTRAK
Penelitian ini merupakan suatu analisis kualitatif tentang kepribadian tokoh Jamila yang terdapat dalam naskah drama "Pelacur dan Sang Presiden" karya Ratna Sarumpaet ditinjau dari gerakan feminisme liberal. simpulan kepribadian tokoh Jamila; mempunyai kepribadian Koleris; egois, emosional, pemberontak, orang yang bisa berkomunikasi secara terbuka dengan orang lain, berorientasi pada tujuan, mempunyai kualitas kepemimpianan sejak lahir, mempunyai sikap menantang, keras kepala, bebas, mandiri, disipin dalam hidup, mengoreksi yang tidak benar, serba memaksa, membuat keputusan dengan segala konsekuensinya, mengambil kuasa dengan cepat dan tegas, lebih tertarik mencapai tujuan daripada menyenangkan hati orang lain, kurang ramah tamah, jujur, ingatan kuat, imajinasi kuat, rasa benci kuat, jarang dicintai, banyak orang takut padanya, sulit memahami titik tolak pemikiran orang lain, berjuang sampai tujuan tercapai, pikiran diisi tujuan cita-cita dan rencana, orang yang tekun bekerja, daya tahan kuat, lebih banyak menyelesaikan pekerjaan dari watak lainnya. Kepribadian tokoh Jamila ditinjau dari Gerakan Feminisme Liberal; (1) perempuan harus berpikir rasional, perempuan tidak lebih lemah dari laki-laki, apabila mendapat represi maka perempuan berhak untuk melawan, (2) menolak pola pikir yang membelenggu untuk tidak mendapat kebahagiaan, (3) memperjuangkan masyarakat agar wajib memberikan pendidikan kepada perempuan seperti halnya pendidikan kepada laki-laki, (4) menolak peran gender yang opresif, yaitu peran yang digunakan sebagai alasan untuk memberikan tempat yang rendah bagi perempuan atau tidak memberikan tempat sama sekali.
\end{abstract}

Kata kunci : Kepribadian, Tokoh Jamila, Naskah Drama Pelacur dan Sang Presiden, Gerakan Feminisme Liberal.

\section{PENDAHULUAN}

Jika membaca karya sastra hakikatnya adalah membaca keadaan masyarakat dan budaya yang terungkap dalam karya itu, karena sastra menyimpan pemikiran sastrawannya yang mengalir dari kenyataan-kenyataan hidup yang mencuatkan pandangan, tafsiran, sikap, dan nilai-nilai kehidupan berdasarkan daya kreasi dan imajinasi pengarangnya, serta kebenarannya dapat dipertanggungjawabkan. Maka membaca karya sastra membuat kita belajar tentang kehidupan, namun kita tidak menyadari 
FON ; Jurnal Pendidikan Bahasa dan Sastra Indonesia

Volume 12 Nomor 1 Tahun 2018

betapa banyak manfaat yang kita dapat imaji yang tertuang dalam dialog. dari hasil membaca, sehingga kita Penafsiran ini bergantung juga pada kekurangan minat baca, apalagi tingkat pengetahuan pembaca, semakin si memperdalam bacaan yang kita baca, pembaca memiliki pengetahuan yang luas terlepas dari apa saja yang kita baca.

Sastra itu sendiri adalah wadah atau maka tingkat penafsirannya pun semakin baik. Apa yang menjadi maksud dari sarana yang pengarang gunakan untuk pengarang tidaklah harus sesuai dengan menyampaikan amanat-amanatnya kepada pembaca melalui media bahasa baik lisan maupun tulisan. Apa yang menjadi amanat pengarang biasanya lahir dari kenyataann hidup yang dialaminya. Maka tidak heran kalau karya sastra tidak serta merta hanya memotret kehidupan semata tapi juga sebagai bentuk respon ungkapan hati pengarang akan kenyataan hidup yang dialaminya tersebut. Karya sastra mengandung keindahan sehingga pembacanya tidak akan cepat merasa jenuh saat membaca karya sastra tersebut. Karya sastra akan semakin menemukan kekuatannya apabila semakin sering diapresiasi, dikaji dan diimplementasikan dalam kehidupan nyata.

Ada berbagai jenis yang kita tahu dari karya sastra yaitu salah satunya adalah drama. Tidaklah mudah untuk langsung memahami apa yang dimaksudkan oleh pengarang, karena tingkat pemahaman pembaca pastinya berbeda-beda bergantung penafsiran si pembaca itu sendiri menafsirkan imajiapa yang menjadi tafsiran pembaca. Drama merupakan jenis karya sastra yang memiliki nilai dan makna yang baik bagi siapapun yang membacanya. Tokoh yang ditampilkan dalam drama adalah pribadi yang ditampilkan yang oleh pembacanya ditafsirkan memiliki kualitas nalar moral dan kecenderungan tertentu seperti yang diekspresikan dalam bentuk tindakan. Dalam menuliskan karyanya pengarang menampilkan kepribadian manusia ke dalam penokohan, sehingga penokohan adalah suatu yang tidak bisa dihilangkan dalam menciptakan karya sastra khususnya drama. Tidak dapat dipungkiri bahwa dengan adanya penokohan akan membuat karya tersebut telihat lebih menarik dan nyata. Sebuah naskah drama yang menjadi pilihan penulis untuk objek penelitian ini adalah naskah drama "Pelacur dan Sang Presiden" karya Ratna Sarumpaet. Alasan penulis memilih naskah ini karena didalamnya menceritakan bagaimana perjuangan seorang perempuan yang mencoba 
melawan dan menghapuskan pandangan akan perempuan yang selalu dipandang lemah dan memiliki derajat yang rendah dibanding laki-laki sebagai hasil dari kebodohan perempuan yang tidak mendapatkan pendidikan yang setara seperti apa yang didapatkan oleh laki-laki sehingga berpengaruh pada perkembangan nalar dan moralnya. Semnagat feminisme itulah yang melekat pada tokoh utama Jamila dalam naskah drama "Pelacur dan Sang Presiden" karya Ratna Sarumpaet, dengan melihat pemberontakan yang dilakukan.

Naskah ini menyajikan sesuatu yang berbeda. Watak tokoh yang khas, ikatan cerita dan konflik yang menarik, serta peristiwa-peristiwa yang dialami tokohnya membuat naskah ini banyak diminati oleh pembaca untuk hanya sekedar dibaca maupun untuk dipentaskan.

Melihat realita tersebut, maka pantaslah naskah ini dipandang khusus sebagai naskah yang menonjolkan pemberontakan perempuan atas keterjajahan mereka terhadap laki-laki yang sekarang lebih dikenal dengan istilah feminisme. Ratna Sarumpaet sebagai pengarang naskah ini menyajikan sebuah kenyataan yang selama ini ada dalam masyarakat Indonesia yaitu kenyataan bahwa praktik pelacuran sudah sangat merajalela di masyarakat kita dan hendaknya dicari jalan keluarnya. Kenyataan ini tidak lain adalah hasil dari tidak setaranya tingkat pendidikan dan tentunya faktor ekonomi sehingga membuat para perempuan kemampuan bernalarnya apatis memandang baik buruknya apa yang mereka lakukan.

Oleh karena kekhasan yang terdapat dalam naskah drama "Pelacur dan Sang Presiden" karya Ratna Sarumpaet, penulis berusaha menganalisis kepribadian tokoh utama Jamila ditinjau dari gerakan feminisme liberal.

Berdasarkan latar belakang masalah di atas, penulis merumuskan masalah (1) bagaimanakah kepribadian tokoh Jamila yang terdapat dalam naskah drama "Pelacur dan Sang Presiden" karya Ratna Sarumpaet?; bagaimanakah kepribadian tokoh Jamila yang terdapat dalam naskah drama "Pelacur dan Sang Presiden" karya Ratna Sarumpaet ditinjau dari gerakan feminisme liberal?

\section{METODE PENELITIAN}

Pada penelitian ini metode penelitiannya yaitu kualitatif. Metode 
FON ; Jurnal Pendidikan Bahasa dan Sastra Indonesia

Volume 12 Nomor 1 Tahun 2018

kualitatif menurut Ratna (2011: 47)

adalah:

"Metode kualitatif memanfaatkan

cara penafsiran dengan menyajikannya dalam bentuk deskripsi dan memberikan perhatian terhadap data alamiah, data dalam hubungannya dengan konteks keberadaannya".

\section{HASIL PENELITIAN DAN}

\section{PEMBAHASAN}

1. Tokoh Jamila memiliki kepribadian Koleris yang kuat. Hal ini dapat dibuktikan dari sifatnya yang egois, emosional, dan pemberontak. Jamila adalah orang yang bisa berkomunikasi secara terbuka dengan orang lain, berorientasi pada tujuan, dan mempunyai kualitas kepemimpinan sejak lahir. Selain itu, Jamila juga mempunyai sikap menantang, keras kepala, bebas, mandiri, dan disiplin dalam hidup. Apabila ada yang ia rasa tidak benar, maka Jamila akan mengoreksinya. Serba memaksa, membuat keputusan dengan segala konsekuensinya, mengambil kuasa dengan cepat dan tegas. Jamila adalah tipe orang yang lebih tertarik untuk mencapai tujuannya daripada menyenangkan hati orang lain. Dalam bersikap ia

kurang ramah tamah, namun jujur, ingatan kuat, dan imajinasinya juga kuat. Perasaan benci sangat kuat, jarang dicintai dan banyak orang takut pada Jamila. Sulit memahami titik tolak pemikiran orang lain, dan Jamila tipe orang yang akan berjuang sampai tujuan tercapai. Pikiran diisi tujuan, cita-cita, dan rencana. Dalam hal pekerjaan, Jamila adalah orang yang tekun, daya tahannya kuat, dan lebih banyak menyelesaikan pekerjaan daripada watak yang lainnya. Pengaruh kepribadian koleris pada aktivitas yang Jamila lakukan sangat terlihat dari dorongan emosiemosinya dalam melakukan segala aktivitasnya. Kepribadian Jamila tidak terbentuk hanya dari sifat dasar lahiriyahnya saja, namun terbentuk karena konflik-konflik yang ia alami dalam hidup. Dengan kepribadian kolerisnya, tokoh Jamila menggunakan pertahanan dengan bentuk Ingatan, Distorsi Perseptual, Katarsis, Persona, dan Pengingkaran. Hubungan kepribadian koleris dalam diri Jamila dengan bentuk pertahanan yang ia lakukan adalah bahwa orang yang memiliki kepribadian koleris akan lebih sering menggunakan 
emosi-emosi dalam mempertahankan citra dirinya.

2. Kepribadian tokoh Jamila ditinjau dari gerakan feminisme liberal: (1) Perempuan harus berpikir rasional, tidak hanya mengharap belas kasihan dari laki-laki. Perempuan tidak lebih lemah dibandingkan laki-laki. Apabila perempuan mengalami penindasan, maka perempuan berhak untuk memberontak. Karena sejatinya jenis kelamin biologis seseorang tidak seharusnya menjadi alat untuk menentukan gender psikologis maupun sosialisnya, (2) Jamila menolak pola pikir yang ingin membelenggu perempuan untuk tidak mendapatkan kebahagiaannya. Tidak seharusnya seseorang menghalangi proses pencapaian kebahagiaan tersebut. Biarkanlah perempuan mengejar apa yang mereka inginkan, (3) Jamila memperjuangkan masyarakat agar wajib memberikan pendidikan kepada perempuan, seperti juga kepada laki-laki, karena semua manusia berhak mendapatkan kesempatan yang setara untuk mengembangkan kapasitas nalar dan moralnya, sehingga mereka dapat menjadi manusia yang utuh, (4) Jamila menolak peran gender yang opresif, yaitu peran yang digunakan sebagai alasan atau pembenaran untuk memberikan tempat yang lebih rendah atau bahkan tidak memberikan tempat sama sekali kepada perempuan baik dalam akademi, forum, maupun pasar. Jamila tidak sependapat dengan peran gender opresif tersebut, bahwa tidak seharusnya jenis kelamin biologis sebagai perempuan mengakibatkan seseorang ditempatkan di pekerjaan yang rendah atau tidak bisa menggeluti pekerjaan yang dilakukan laki-laki.

\section{SIMPULAN}

Tokoh Jamila mempunyai kepribadian koleris (kuat) dan menganut faham feminisme liberal, yaitu: (1) Perempuan harus berpikir rasional, tidak hanya mengharap belas kasihan dari laki-laki. Perempuan tidak lebih lemah dibandingkan laki-laki. Apabila perempuan mengalami penindasan, maka perempuan berhak untuk memberontak. Karena sejatinya jenis kelamin biologis seseorang tidak seharusnya menjadi alat untuk menentukan gender psikologis maupun sosialisnya, (2) Jamila menolak pola pikir yang ingin membelenggu perempuan untuk tidak mendapatkan 
FON ; Jurnal Pendidikan Bahasa dan Sastra Indonesia

Volume 12 Nomor 1 Tahun 2018

kebahagiaannya. Tidak seharusnya

Boeree, George C. 2008. Personality

seseorang menghalangi proses pencapaian

kebahagiaan tersebut. Biarkanlah

perempuan mengejar apa yang mereka

inginkan, (3) Jamila memperjuangkan

masyarakat agar wajib memberikan pendidikan kepada perempuan, seperti juga kepada laki-laki, karena semua manusia berhak mendapatkan kesempatan yang setara untuk mengembangkan kapasitas nalar dan moralnya, sehingga mereka dapat menjadi manusia yang utuh, (4) Jamila menolak peran gender yang opresif, yaitu peran yang digunakan sebagai alasan atau pembenaran untuk memberikan tempat yang lebih rendah atau bahkan tidak memberikan tempat sama sekali kepada perempuan baik dalam akademi, forum, maupun pasar. Jamila tidak sependapat dengan peran gender opresif tersebut, bahwa tidak seharusnya jenis kelamin biologis sebagai perempuan mengakibatkan seseorang ditempatkan di pekerjaan yang rendah atau tidak bisa menggeluti pekerjaan yang dilakukan lakilaki.

\section{DAFTAR PUSTAKA}

Arikunto, Suharsimi. 2006. Prosedur Penelitian Suatu Pendekatan Praktik. Jakarta: PT. Rineka Cipta

Theories: Melacak Kepribadian Anda Bersama Psikolog Dunia. Yogyakarta: Prismashopie

Brouwer, M.A.W dkk. 1984. Kepribadian dan Perubahannya. Jakarta: Gramedia

Littauer, Florence. 1996. Personality Plus: Bagaimana Memahami Orang Lain Dengan Memahami Diri Anda Sendiri. Jakaeta: Binarupa Aksara.

Graddol, dan Joan Swann. 2003. Gender Voices: Telaah Kritis Relasi Bahasa Jender. Pasuruan: Pedati

Hasanuddin WS. 2015. Drama Karya Dalam Dua Dimensi Kajian Teori, Sejarah, dan Analisis. Bandung: Angkasa

Heryadi, Dedi. 2010. Metode Penelitian Bahasa Indonesia. Bandung: Pustaka Billah

Minderop, Albertine. 2011. Psikologi Sastra: Karya Sastra, Metode, Teori, dan Contoh Kasus. Jakarta: Pustaka Obor

Muslikhati, Siti. 2004. Feminisme dan Pemberdayaan Perempuan dalam Timbangan Islam. Jakarta: Gema Insani Press

Nurgiyantoro, Burhan. 2012. Teori pengkajian Fiksi. Yogyakarta: Gadjah Mada University Press

Nurhayati, Eti. 2012. Psikologi Perempuan Dalam Berbagai Perspektif. Yogyakarta: Pustaka Pelajar

Pusat Pembinaan dan Pengembangan Bahasa. 2008. Kamus Besar Bahasa 
FON ; Jurnal Pendidikan Bahasa dan Sastra Indonesia

Volume 12 Nomor 1 Tahun 2018

Indonesia, Edisi Keempat. Jakarta: Balai Pustaka

Ramdhani, Afindar. 2011. Gambaran Gaya Hidup (Life Style) Beresiko di Kalangan Kaum Homoseksual di Kota Medan. Diakses dari http://repository.usu.ac.id/bitstream/ 123456789/24146/5/Chapter\%20II.p df pada tanggal 13 Februari 2017

Ratna, Nyoman Kutha. 2011. Teori, Metode, dan Teknik Penelitian Sastra. Yogyakarta: Pustaka Pelajar

Rene Wellek dan Austin Warren. 2014. Teori Kesusastraan. Jakarta: Gramedia Pustaka Utama

Sarumpaet, Ratna. 2006. Pelacur dan Sang Presiden. Jakarta: Satu Merah Panggung

Sugianto Mas, Aan. 2013. Langkah Awal Menuju Apresiasi Sastra Indonesia. Kuningan: Universitas Kuningan

Sugianto Mas, Aan. 2014. Kajian Prosa Fiksi \& Drama. Kuningan: Universitas Kuningan
Sugianto Mas, Aan. 2016. Apresiasi Drama. Kuningan: Universitas Kuningan

Sugihastuti dan Itsna Hadi Saptiawan. 2010. Gender dan Inferioritas Perempuan: Praktik Kritik Sastra Feminis. Yogyakarta: Pustaka Pelajar

Teeuw, A. 2003. Sastera dan Ilmu Sastera. Jakarta: Dunia Pustaka Jaya

Tong, Rosemarie Putnam. 2008. Feminist Thought: Pengantar Paling Komprehensif Kepada Arus Utama Pemikiran Feminis. Yogyakarta: Jalasutra

Wikipedia. 2017. Feminisme. Diakses dari http://id.wikipedia.org/wiki/Feminis me pada tanggal 13 Februari 2017.

Wikipedia. 2017. Homoseksualitas.

Diakses dari

https://id.wikipedia.org/wiki/Homoseksual itas pada tanggal 11 Maret 2017. 